\title{
Reforming Scottish Criminal Procedure: In Search of Process Values
}

\author{
PAMELA R. FERGUSON*
}

\section{Introduction}

In recent years there have been several proposals to reform aspects of Scottish criminal procedure. The rationales for these proposals are largely considerations of efficiency, and in particular a desire to improve the accuracy of fact-finding. The procedural rights of suspects and accused persons are acknowledged, but often in a somewhat perfunctory fashion. Since there is no detailed consideration of the values they embody, these rights are vulnerable to interpretation in a way which allows them to be outweighed by other considerations, such as the rights and interest of victims or of the wider society. Features of criminal procedure are assessed solely on their instrumental, or 'truth-finding' abilities, and there is little attempt to offer a normative account. Furthermore, some of the proposed changes would situate Scottish criminal procedure closer to non-adversar-

* Professor of Scots Law, School of Law, University of Dundee, Scrymgeour Building, Park Place, Dundee, DD1 4HN, Scotland, UK. The author is grateful to the participants of the ScottishScandinavian Criminal Law Conversations, held at the University of Glasgow in May 2016. Particular thanks are due to Gustaf Almkvist and Iain Cameron from the Department of Law, University of Uppsala, who acted as discussants of the paper, and to Peter Duff, Alan Page and Jørn Jacobsen for comments on an earlier draft. All links in this paper were last accessed on 10 September 2016.

This is an Open-access article distributed under the terms of the Creative Commons Attribution 3.0 Unported License (http://creativecommons.org/licenses/ by/3.0/, permitting all use, distribution, and reproduction in any medium, provided the original work is properly cited. 
ial and 'inquisitorial' systems, and away from its adversarial roots. ${ }^{1}$ Reform proponents seem untroubled by such a shift, believing that since the purpose of the criminal trial is to attain a high degree of fact-finding accuracy, it matters not whether this is achieved by adversarial or non-adversarial procedures.

This paper describes and critiques the recent proposals and the principles which are said to lie behind them, and draws comparisons with similar efficiency-driven reforms in England and Wales. It argues that there has been too much emphasis on the need for the criminal process to become better at finding 'the truth'. This approach tends to equate erroneous acquittals and wrongful convictions, and by doing so fails to recognise a fundamental tenet of adversarial criminal procedure, namely that protecting the innocent against wrongful conviction is of the utmost importance. The paper also suggests that there should be greater focus on non-instrumental and process values. These values risk being obscured by an exclusive focus on 'the search for the truth'. It is adherence to process values which gives the state the moral legitimacy it needs in order to condemn and punish the accused.

\section{Background}

Criminal procedure may be described as the body of laws and rules which govern the investigation and prosecution of crimes. Its primary purpose is to determine whether those who are suspected of breaching the criminal law are indeed guilty of having done so and are thus deserving of punishment. Substantive criminal law has been described as the "Cinderella subject" of the legal academy' - an essentially practical matter, devoid of much in the way of theory. ${ }^{2}$ Extending the metaphor, criminal procedure is no doubt considered by many to be like Cinderella's broom: a useful tool, perhaps even an essen-

1 Referring to the criminal procedure systems of some Continental European countries as 'inquisitorial' is not particularly accurate; as Brants has suggested: 'Given that almost all modem criminal justice systems combine procedural features of both traditions, it is better to consider them not as being totally adversarial or inquisitorial, but as positioned on a continuum. Indeed, rather than speak of inquisitorial or adversarial systems, it is more accurate to see modem jurisdictions as primarily "shaped by" the inquisitorial or adversarial tradition': Brants, Wrongful convictions and inquisitorial process: the case of the Netherlands, 80 University of Cincinnati Law Review (2012) pp. 1069-1114, at 1073. 'Inquisitorial' is, however, used in the present paper since it is the term employed in recent Scottish reform proposal documents.

2 Farmer, Bringing Cinderella to the ball: teaching criminal law in context, 58 Modern Law Review (1995) pp. 756-766, at 756, quoting Tur, Criminal law and legal theory in Twining (ed.), Legal Theory and the Common Law (Basil Blackwell 1986) p. 195. 
tial one, but not worthy of much consideration, far less of philosophical analysis. ${ }^{3}$ In Scotland, recommendations for changes to criminal procedure have recently become the focus of some debate. However, although the pace of change has accelerated, and the proposed changes have become more radical, philosophical analysis and commentary remain sparse.

Some important procedural changes came about as a result of the case of Cadder $v$. HM Advocate in $2010 .{ }^{4}$ Cadder and its impact have been described elsewhere and will not be considered at length in the present paper. ${ }^{5}$ In brief, the UK Supreme Court found that the failure of Scottish law to recognise a right to legal advice for suspects prior to police questioning was contrary to Article 6 of the European Convention on Human Rights (ECHR), as interpreted by the European Court of Human Rights in Salduzv. Turkey. ${ }^{6}$ The relevant domestic legislation was amended to provide that suspects who are detained ${ }^{7}$ or attend voluntarily at a police station ${ }^{8}$ have a right to a private consultation with a solicitor before questioning, ${ }^{9}$ and also at any time during such questioning. ${ }^{10}$ The Scottish Government invited the Lord President ${ }^{11}$ to nominate a High Court judge to review 'key elements of Scottish criminal law and practice ${ }^{12}$ in light of the decision in Cadder. Lord Carloway took up the task and his 2011 Review made many important recommendations regarding police powers of arrest, and the law and practice of questioning and detaining

3 'Procedure is viewed as theoretically uninteresting, or at least comparatively less interesting than the shape and content of substantive criminal law'. Roberts, Groundwork for a jurisprudential theory of criminal procedure, ch. 17 in Duff and Green (eds.), Philosophical Foundations of Criminal Law (2011) at pp. 379-408, at 380. See also in the same volume: Dripps, The substance-procedure relationship in criminal law, ch. 18 , pp. 409-432, at 410: 'Criminal law has received more attention from academic philosophers than criminal procedure.

4 [2010] UKSC 43; 2011 SC (UKSC) 13; 2010 SLT 1125; 2010 SCL 1265.

5 See Ferguson, Repercussions of the Cadder case: the ECHR's fair trial provisions and Scottish criminal procedure, Criminal Law Review (2011), pp. 743-757; McCluskey, Supreme error, 15 Edinburgh Law Review (2011) pp. 276-287; Leverick, The Supreme Court strikes back, 15 Edinburgh Law Review (2011) pp. 287-292; Stark, The consequences of Cadder, 15 Edinburgh Law Review (2011) pp. 293-298; White and Ferguson, Sins of the father? The 'sons of Cadder', Criminal Law Review (2012) pp. 357-368.

6 (2009) 49 EHRR 19.

7 Criminal Procedure (Scotland) Act 1995, s 15A(a), inserted by the Criminal Procedure (Legal Assistance, Detention and Appeals) (Scotland) Act 2010 (asp 15) s 1.

8 Criminal Procedure (Scotland) Act 1995, s 15A(b) (henceforth: '1995 Act').

91995 Act, s 15A(3)(a).

101995 Act, s 15A(3)(b). These provisions will be replaced by s 32 of the Criminal Justice (Scotland) Act 2016 when that legislation is brought in to force.

11 The Lord President of the Court of Session (a civil court) is also the Lord Justice General of the High Court of Justiciary (a criminal court), and as such is Scotland's most senior judge.

12 The Carloway Review: Report and Recommendations (2011) (henceforth: '2011 Review') para. 1.0.1. The report is available at: http://www.scotland.gov.uk/Resource/Doc/925/0122808.pdf. 
suspects. ${ }^{13}$ The Review proved highly controversial, particularly its recommendation that the requirement for corroborated evidence be abolished. ${ }^{14}$ The resulting legislation made many changes to police powers of arrest and suspects' rights during police detention, but the proposal regarding corroboration was dropped from the Bill and is to be subject to further consideration by the Scottish Government. ${ }^{15}$

The focus of this paper is on more recent proposals. It is, however, notable that the 2011 Review defined 'miscarriages of justice' in a 'broad sense, ${ }^{16}$ that is, as including erroneous acquittals as well as wrongful convictions. ${ }^{17}$ That acquittal of those who are in fact guilty should be regarded not merely as an inaccurate verdict, but as a miscarriage of justice is not the usual understanding of that term. This is discussed further, below. The practice adopted in the 2011 Review - recommendations for profound changes to criminal procedure emanating from one person - has been criticised. ${ }^{18}$ However, the mechanisms of reform are not the subject of this paper. Rather, it considers the extent to which recent proposals reflect underlying process values. Process values are often at risk of being sacrificed to outcomes since their underlying principles are not always readily apparent and can be difficult to articulate. There is a danger that they become viewed as purely technical matters, hence of lesser importance than the outcome - accurate and efficient fact-finding - that they are assumed to serve. ${ }^{19}$ This paper argues that many process values promote other goals, rather than that of ascertaining 'the truth'. Although the paper focuses mainly on Lord Carloway's proposals, this should not be construed as a personal

13 For the full terms of reference see 2011 Review, pp. 13-14. These are also listed in the Scottish Government Consultation Paper, Reforming Scots Criminal Law and Practice: The Carloway Report, p. 5, available at: http://www.gov.scot/resource/0039/00396483.pdf

14 For a summary and critique of the proposals see Ferguson and Raitt, A clear and coherent package of reforms? The Scottish Government Consultation Paper on the Carloway Report, in Criminal Law Review (2012) pp. 909-926; Chalmers and Leverick, 'Substantial and radical change': a new dawn for Scottish criminal procedure? in 75 Modern Law Review (2012) pp. 837864 .

15 Scottish Government, Corroboration abolition removed from Bill (press release), 21 April 2015, available at http://news.scotland.gov.uk/News/Corroboration-abolition-removed-fromBill-1866.aspx_(last accessed 16 August 2016). See now Part 1 of the Criminal Justice (Scotland) Act 2016.

16 Carloway Review, para 7.2.30.

$17 \quad$ Ibid. para. 7.2.42.

18 See Chalmers, Criminal law reform in Scotland, 19 Edinburgh Law Review (2015) pp. 399-403. Chalmers and Leverick have referred to the Carloway Review as 'part of a quite extraordinary process of law reform. Never before in the history of Scottish - or English - criminal procedure has wide ranging law reform been potentially so dependent on the views of a single individual' (Chalmers and Leverick 2012 p. 862). See also at 839: 'This is a model for criminal law reform without recent precedent?

19 See Summers, Evaluating and improving legal processes - a plea for 'process values', 60 Cornell Law Review (1974) pp. 1-52, at 41-42. Summers' views are discussed further, below. 
attack; his Lordship is to be commended for fostering debate on the modernisation of the criminal process and many of his suggestions are to be welcomed. The concern, however, is that there has been little theoretical analysis of Scottish criminal procedure, more generally, and that these latest reform proposals continue this approach. ${ }^{20}$

\title{
3. The Recent Proposals
}

In May 2013 Lord Carloway delivered a conference speech at Murrayfield in Edinburgh, in which he called for 'clear sky thinking on how best to prove or disprove fact [sic] efficiently and in the interests of justice in the modern age, given the advances in technology which have occurred over the last twenty years'. ${ }^{21} \mathrm{He}$ described the current Scottish criminal process as being largely based on the procedures used in the Victorian era:

\begin{abstract}
The central pillar of the procedure is the trial; the show piece at which almost everyone involved in the case comes, or ought to come, together in one place at the same time before judge, jury and the public gaze. The singular feature of the proof is oral testimony; that is an account given upon oath, from the witnesses appearing at that diet. This is the mode of enquiry deemed the best way of establishing the truth of whatever is alleged to have happened or at least whether the accused committed the crime charged. The "best evidence" then is sworn testimony. ${ }^{22}$
\end{abstract}

According to Lord Carloway, the current practice in Scottish trials whereby witnesses are generally required to give evidence in person was 'time consuming, expensive and unnecessary in the modern era'. ${ }^{23}$ Instead, he proposed that video or audio recordings should be made of witnesses' police statements, and these should be used as evidence at trial instead of live, oral testimony. ${ }^{24}$

He also favoured a more episodic approach to the trial, which should cease to be the point at which the court would hear testimony from all the witnesses. Rather, it should mark the stage by which all relevant information ought to have been placed before the

20 This may well be part of a wider problem; John Langbein has suggested that examination of English legal history reveals 'a criminal process for which we have no adequate theory'. Langbein, The Origins of Adversary Criminal Trial (Oxford University Press 2003) at 9.

21 Lord Carloway, Scots criminal evidence and procedure - meeting the challenges and expectations of modern society and legal thinking (Murrayfield, 9 May 2013) p. 10, available at: http:// www.scotland-judiciary.org.uk/26/1045/Lord-Justice-Clerks-speech-at-the-Criminal-LawConference (henceforth: 'Murrayfield lecture').

22 Murrayfield lecture, at 2.

$23 \quad$ Ibid. pp. 26-27.

$24 \quad$ Ibid. p. 7. 
court, so that the lawyers from both sides could then make their submissions on the evidence. ${ }^{25}$ Predicting the demise of the 'lengthy trial' at which all witnesses testify in person in court, he concluded that: 'We ought to be moving towards a situation where the trial diet is the day set down for the final determination of the case. ${ }^{26}$ In August 2014 Lady Dorian, at that time a High Court judge and now the Lord Justice Clerk, ${ }^{27}$ gave a speech entitled 'Digital Justice Strategy: A view from the courts. ${ }^{28}$ She too championed the use of new technologies 'to make evidence more reliable and more readily available, and to make processes and procedures more efficient. ${ }^{29}$ Like Lord Carloway, Lady Dorian stressed the 'potentially huge benefits to be gained from capturing evidence from witnesses, available for use in court, at an early stage..$^{30}$

The Evidence and Procedure Review was an internal Scottish Court Service research project led by Lord Carloway which expanded on some of the themes in his Murrayfield lecture. ${ }^{31}$ The resulting report, published in March 2015, explained that the Scottish Court Service and Scottish Government had become concerned that the criminal process 'was not becoming significantly quicker or more efficient' 32 and that '[t] his inefficiency was, in itself, contributing to the obstruction of justice and the frustration of the search for the truth. ${ }^{33}$ It reiterated the belief that 'modernisation of the rules of evidence and procedure could make a substantial contribution to improving the fairness, efficiency and effectiveness of trials, and would contribute to the core aim of enhancing the trial's role in discovering the truth' ${ }^{34}$ The Review set out 'principles for reform'. According to these principles, Scotland should aspire to a system:

- in which the trial process is and is seen to be fair to all the parties involved;

$25 \quad$ Ibid. pp. 17-18.

$26 \quad$ Ibid. pp. 26-27. See also Lord Carloway's Keynote address to the 15th Annual 21st Century Bar Conference 2015 (henceforth 'Bar Conference address') at 14 (available at: http://www.scotlandjudiciary.org.uk/Upload/Documents/ LJC21stCenturyBarConference20154December2015.pdf).

27 The Lord Justice-Clerk is the second most senior judge in Scotland, after the Lord JusticeGeneral. See footnote 11, above.

28 Available at: http://www.scotland-judiciary.org.uk/26/1301/Speech-by-Lady-Dorrian-at-thelaunch-of-The-Digital-Strategy-for-Justice-in-Scotland

$29 \quad$ Ibid. at 3.

$30 \quad$ Ibid. at 5.

31 The other members of the Review team were Lady Dorrian, Sheriff Principal Craig Scott and Eric McQueen, Chief Executive of the Scottish Court Service.

32 Scottish Court Service, Evidence and Procedure Review Report, (March 2015) available at: http:// www.scotcourts.gov.uk/docs/default-source/aboutscs/reports-and-data/reports-data/evidenceand-procedure-full-report---publication-version-pdf.pdf?sfvrsn=2 (henceforth '2015 Review') at para 1.3.

$33 \quad$ Ibid.

$34 \quad$ Ibid. at para 1.4 . 
Bergen Journal of Criminal Law and Criminal Justice • 2/2016

- which deals with cases efficiently and timeously, reaching a conclusion within a reasonable time;

- which provides access to justice for all;

- which provides protection for all parts of society against the damage that crime can cause;

- in which the experience of the participants, including victims, witnesses and jurors, is a positive one;

- which is reasonably simple to operate, with clear, readily understandable rules; and

- which is relevant to the everyday lives of the people and society it serves, and retains their trust and confidence. ${ }^{35}$

The 2015 Review also made recommendations for reform of the taking of evidence of children and other vulnerable witnesses in advance of the trial, with Western Australia, England \& Wales, and Norway being considered as potential models for Scotland. ${ }^{36}$ Norwegian law provides for pre-trial hearings at which children or other vulnerable witnesses are questioned soon after a crime has been reported. The interviews are conducted in a Barnehus, a State Children's House, ${ }^{37}$ and although the accused is not generally present (indeed, there may not be an identified suspect at this stage) prosecution and defence lawyers attend the hearing. ${ }^{38}$ The lawyers do not, however, question the witness; this is done by a specially trained police officer. ${ }^{39}$ The 2015 Review team visited a Barnehus and described it as an 'outstanding facility'..$^{40}$ The Australian and English systems also allow for the pre-trial recording of statements from child witnesses, but cross-examination of the witness often does not occur until several months later, and is conducted by the accused's own lawyer. ${ }^{41}$

$35 \quad$ Ibid. para 1.7.

$36 \quad$ Ibid. ch. 2. Vulnerable witnesses can already have their evidence in chief take the form of a pretrial written statement. See the Criminal Procedure (Scotland) Act 19915, s 271M, inserted in 2004.

$37 \quad$ Ibid. para 2.51 .

$38 \quad$ Ibid. para 2.52.

$39 \quad$ Ibid. para 2.54.

$40 \quad$ Ibid. para 2.61

${ }^{41}$ See ibid. paras 2.23 to 2.33, and paras 2.34 to 2.47 for descriptions of the Australian and English systems, respectively. The pre-recording of witness statements was first advocated in England and Wales by an Advisory Group on Video Evidence in 1989 chaired by Thomas Pigot, QC. Where both the evidence-in-chief and the cross-examination of a witness are recorded pre-trial, this has become known as a 'Full Pigot', and where only the former is recorded this is described as a 'Half Pigot' (see ibid. para 2.20). 
While ultimately favouring the Norwegian example, ${ }^{42}$ the Review did recognise that its adoption would require major changes to Scottish law, procedures and culture. ${ }^{43}$ One difficulty is the importance placed in the Scottish system on the cross-examination of prosecution witnesses by the defence lawyer at the trial itself. The Review advocated change here, too, stating:

\section{It is now widely accepted that taking the evidence of young and vulnerable witnesses requires special care, and that subjecting them to the traditional adversarial form of examination and cross-examination is no longer acceptable. ${ }^{44}$}

The Review argued that cross-examination was 'essentially destructive, aiming to undermine or discredit the witness and their testimony', thus it was no longer appropriate to subject young or otherwise vulnerable witnesses to it. ${ }^{45}$ It concluded that the examination of all witnesses need not be conducted at the trial itself, so long as this was supervised by an impartial judicial authority, ${ }^{46}$ and reiterated the proposal that the Scottish Parliament enact legislation to allow pre-recorded witness statements to replace oral testimony. ${ }^{47}$ Further examination of the witness at the trial could be permitted on application to the court, but the form and content of this 'need not follow current adversarial practice'. 48 The proposals would require judges to play a more active role in case management, to ensure that defence lawyers do not specify, as a matter of routine, that they need to cross-examine all prosecution witnesses. ${ }^{49}$ Pre-recorded evidence is regarded as hearsay in Scots law, and as a general rule hearsay evidence is inadmissible since it is not regarded as being the best evidence. ${ }^{50}$ This is in large part based on the fact that it is not susceptible to cross-examination. If Scotland is to permit pre-recorded witness statements to replace oral testimony, it will also require to amend its laws on hearsay.

The 2015 Review floated some general ideas for reform for consideration by the Scottish Government, rather than delineating concrete recommendations; as Lord Carloway

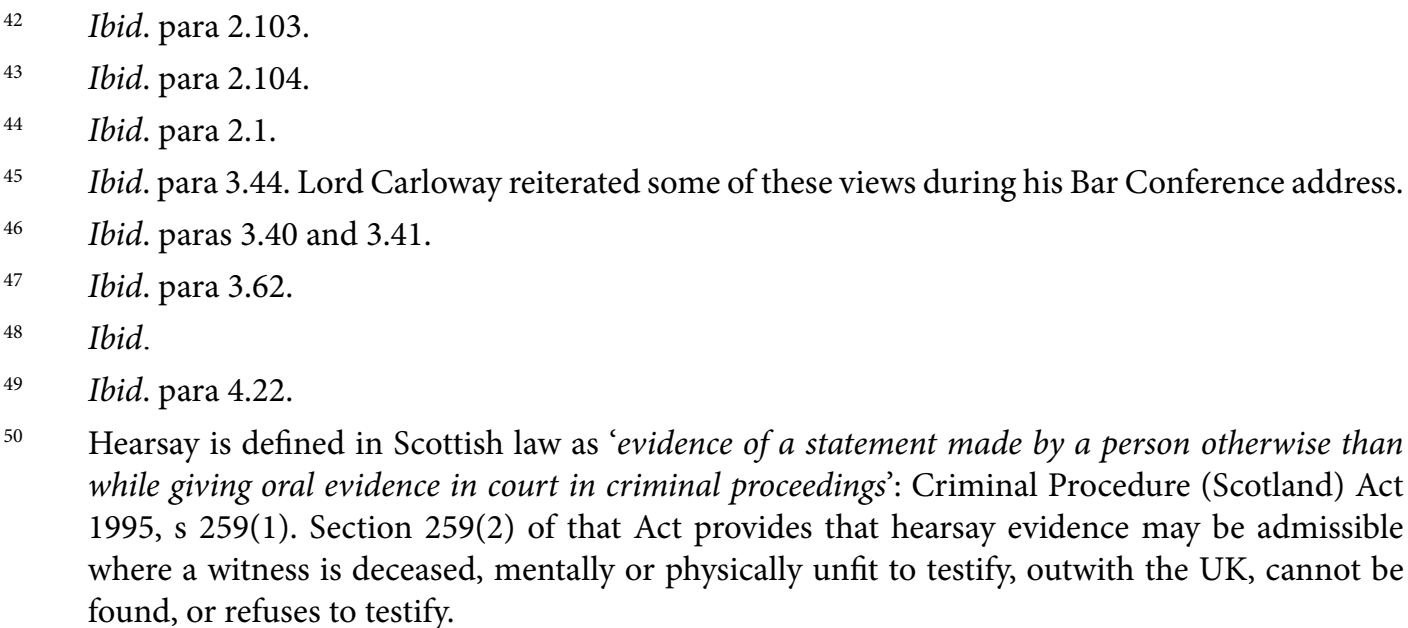


made clear at an event organised to mark the Review's publication, it was 'not a fully developed, fully costed and evaluated set of policy proposals, and was never intended to $b e .{ }^{51}$ Noting that his suggestions relating to cross-examination had been criticised in the media, Lord Carloway took this opportunity to explain that

the Review does not advocate a diminution of the right of cross-examination to the detriment of the rights of the accused. The Review fully acknowledges that the requirement for a fair trial means that there is a right for an accused to examine or have examined any witness against him .... What the Review does do is provoke consideration of what it is that cross-examination should be trying to achieve, and how it might best be conducted to reveal the truth ... ${ }^{52}$

As we shall see, this emphasis on 'revealing the truth' was a central theme of the Review and subsequent proposals.

The Scottish Courts and Tribunals Service organised workshops and discussion groups for lawyers, academics and other interested parties to consider some of the Review's recommendations, focusing in particular on the taking of evidence from children and other vulnerable witnesses. ${ }^{53}$ This produced a further report: Evidence and Procedure Review - Next Steps, in February $2016 .{ }^{54}$ While mainly summarising the group discussions, Next Steps concluded:

The principal recommendation is that, initially for solemn cases [that is, the most serious cases, prosecuted on indictment before a jury], there should be a systematic approach to the evidence of children or vulnerable witnesses in which it should be presumed that the evidence in chief of such a witness will be captured and presented at trial

51 Evidence and Procedure Review Launch, p. 2, available at: http://www.scotcourts.gov.uk/docs/ default-source/SCS-Communications/evidence-and-procedure-review-launch.pdf?sfvrsn=2

$52 \quad$ Ibid. at 8.

53 The Scottish Courts and Tribunals Service is the new name for the Scottish Courts Service, from 1 April 2015. The Next Steps report (below) also considered issues relating to a move to digitised evidence which would facilitate its storage and sharing (see Part A of the report), but these raise mainly practical issues of a technical nature hence are not within the scope of the present paper.

54 Scottish Courts and Tribunals Service, Evidence and Procedure Review-Next Steps (26 February 2016), available at: http://www.scotcourts.gov.uk/docs/default-source/SCS-Communications/ evidence-and-procedure-report---next-steps---february-2016.pdf?sfvrsn=2 (henceforth: Next Steps). 
in pre-recorded form; and that the subsequent cross-examination of that witness will also, on application, be recorded in advance of trial. ${ }^{55}$

The above recommendations, and the concomitant changes to the trial structure and the law on hearsay, have not yet been enacted. It took five years for the proposals in the first Carloway Review to become law, but this was in large part due to the controversy engendered by the proposal to abolish the requirement for corroborated evidence. These latest recommendations may well be enacted more quickly.

On becoming Lord Justice-Genera ${ }^{56}$ in 2016 , Lord Carloway used the occasion of his installation as an opportunity to comment on some current procedural issues, including pre-trial time limits. Scottish legislation provides that in cases prosecuted under solemn procedure, ${ }^{57}$ once an accused person has been fully committed for trial and remanded in custody the trial must commence within 140 days. ${ }^{58}$ The provision is intended to minimise the amount of time accused persons spend in custody prior to trial, ${ }^{59}$ and has been referred to as 'the jewel in the crown' of the Scottish criminal justice system. ${ }^{60}$ The time limit was previously 110 days and the court had to be satisfied that any delay was not due to the fault of the prosecution. The period was increased in 2004 to its current 140 days, and it was also provided that this could be extended by a court 'on cause shown'. ${ }^{61}$

55 Ibid., at para 74. Later in the same week Lord Carloway criticised cross-examination techniques used in rape trials: See Scottish Legal News, 29 February 2016, available at http://www. scottishlegal.com/2016/02/29/lord-carloway-calls-for-alleged-rape-victims-to-be-protectedagainst-aggressive-cross-examination/. This reiterated concerns he had raised six months previously: see 'Lord Carloway warns lawyers over sex crime victim questioning', BBC News, 7 August 2015, available at: http://www.bbc.co.uk/news/uk-scotland-33823225. For a response from the Scottish Criminal Bar Association (SCBA) see 'SCBA responds to Lord Carloway's comments on alleged rape victims', Scottish Legal News, 1 March 2016, available at: http://www. scottishlegal.com/2015/08/10/scba-responds-to-lord-carloways-comments-on-alleged-rapevictims/.

56 See footnote 11 , above.

$57 \quad$ Solemn cases are those prosecuted on indictment, before a judge and a jury. Less serious cases are prosecuted using summary procedure, that is, without a jury. The maximum penalty in the latter type of case is 12 months' imprisonment and/or a fine of $£ 10,000$.

58 Criminal Procedure (Scotland) Act 1995, s 65(4): ‘... an accused who is committed for any offence until liberated in due course of law shall not be detained by virtue of that committal for a total period of more than ... 140 days, unless the trial of the case is commenced with that period, which failing he shall be admitted to bail.

59 Limitation periods for pre-trial incarceration have applied in Scotland since the Act Anent Wrongeous Imprisonment 1701. See Shiels et al., Green's Annotated Acts: Criminal Procedure (Scotland) Act 1995 (13 ${ }^{\text {th }}$ edn, 2014), para A4-148. It seems that the 1701 Act was 'popularly known as the Habeas Corpus Act of Scotland': Greaves, Art II - criminal procedure, Law Magazine and Law Review, or Quarterly Journal of Jurisprudence (1866-1867), 22:2, pp. 191-223, at 194.

$60 \quad$ Ibid.

61 Criminal Procedure (Scotland) Act 1995, s 65(5). 
The time period is now being breached in High Court trials on a regular basis, and it has been suggested that the more liberal 'cause shown' ground is being interpreted by the courts to allow postponement where the prosecution is unprepared for trial due to a lack of resources..$^{62}$ Commenting on these breaches of the time limit, Lord Carloway stated:

The issue for the future will be whether, in the era of statutory disclosure [of evidence, pre-trial], scientific analysis of DNA findings and the recovery and detailed scrutiny of text and email messaging, the narrow window allowed by statute for the commencement of a trial is sustainable or in accord with modern principles of fairness or justice. ${ }^{63}$

\title{
4. An Assessment
}

Lord Carloway's suggestion that video recordings of witnesses' statements should be used at trial instead of live testimony is a welcome reform proposal. Peter van Koppen has described the Dutch approach:

\begin{abstract}
Suppose I had been a witness to a robbery and two years later, or even a year later the trial is scheduled. The day of the robbery I gave an extensive statement to the police, which was recorded by the police, written down in a document, put into the file. What would be a better statement? My fresh memory on the day of the robbery or my degraded memory, influenced by all kinds of stories told by others who are reading in newspapers or discussing with other witnesses a year later at trial? Probably the better answer is the original memory. ${ }^{64}$
\end{abstract}

If the written record of a witness's police statement is likely to be more accurate than an oral testimony several months later at the trial, how much more accurate is an audio-visual recording of that police interview, taken perhaps just a few hours or even minutes after the commission of the offence? The recommendation that Scottish law embrace technology in this way has much to commend it. Before implementing such a change,

62 Scottish Legal News, Constant breaches of 140 day rule 'oppressive and unconstitutional', 13 November 2015, available at: http://www.scottishlegal.com/2015/11/13/constant-breaches-of140-day-rule-oppressive-and-unconstitutional/

63 Lord Carloway, Speech by the Lord President, 8 January 2016, available at http://www.scotlandjudiciary.org.uk/Upload/Documents/LPSpeechInstallationFriday8January2016.pdf. See also: New Lord President calls survival of 140 day rule into question, Scottish Legal News, 8 January 2016, available at: http://www.scottishlegal.com/2016/01/08/new-lord-president-calls-survivalof-140-day-rule-into-question/

64 Van Koppen, Miscarriages of justice in inquisitorial and accusatorial legal systems, 7 Journal of the Institute of Justice and International Studies (2007) pp. 50-58, at 53. 
however, there needs to be a full assessment of its impact on the accused's right to challenge the prosecution's case. This requires careful analysis of the value of the right and the role it plays in the trial - which in turn requires articulation of a philosophy of the criminal process.

Lord Carloway is not the first judge who may be said to have favoured a pragmatic approach to law reform, nor is his review the first to be criticised for a lack of theory. ${ }^{65}$ In 1993 the Royal Commission on Criminal Justice (the Runciman Commission) ${ }^{66}$ proposed reforms to the criminal process in England and Wales, following the acquittal of the Guildford $4^{67}$ and the Birmingham $6{ }^{68}$ Lacey has criticised the 'theoretical vacuum ... at the heart of the Royal Commission's Report. ${ }^{\prime} 9$ Similar criticisms were also made by other academic commentators, who noted that there was 'very little attempt ... to discuss what the aims and objectives of the criminal justice system ought to be. ${ }^{30}$ To be fair to both distinguished judges, they are not alone in taking an atheoretical approach to criminal procedure; as Roberts has observed: 'To the best of my knowledge, there has never been any grand conspiracy to keep Criminal Law Theory pure and uncontaminated by criminal procedure scholarship. Procedural issues have simply been ignored by the vast majority of card-carrying criminal law theorists. ${ }^{71}$ Thus it seems that legal theorists do not tend to

65 See: Editorial, The end of the trial as we know it, 141 Criminal law Bulletin (2016) pp. 1-3.

66 Report of the Royal Commission on Criminal Justice, 1993, Cmnd 2263.

67 The Guildford 4 (1974) 'were convicted solely on the basis of confessions which they always claimed were beaten out of them during the seven days they were interrogated under the [prevention of terrorism legislation]'. Hillyard, The politics of criminal injustice: the Irish dimension in Criminal Justice in Crisis, eds. McConville and Bridges (Edward Elgar 1994) pp. 69-79, at 73.

68 The Birmingham 6 (1975) 'were convicted on the basis of four confessions and forensic evidence. They ... consistently argued that these statements were beaten out of them' (ibid). Other cases of miscarriages of justice which came to light in the early 1990s include that of Judith Ward (1974), the Maguire family (1976), and Stephan Kiszko (1976). A detailed examination of miscarriages of justice in English law concluded that there was 'a significant gap between the values claimed for criminal justice and its procedures and practices': Nobles and Schiff, Understanding Miscarriages of Justice (Oxford University Press 2000) at 35.

69 Lacey, Missing the wood ... pragmatism versus theory in the Royal Commission, in Criminal Justice in Crisis, eds. McConville and Bridges (Edward Elgar 1994) pp. 30-41.

70 Jackson, Trial by jury and alternative modes of trial, in McConville and Bridges 1994 at 256. See also in the same volume: Maher, Reforming the criminal process: a Scottish perspective, pp. 59-68, at 59, and Bridges and McConville, Keeping faith with their own convictions: the Royal Commission on Criminal Justice, pp. 3-23, at 5: Bridges and McConville accuse the Report of 'fudging and compromising on issues of principle and providing a strangely piecemeal, incoherent and seemingly contradictory analysis of the system and set of proposals for change.

71 Roberts 2011 at 380. Roberts offers 'four rival perspectives or approaches to conceptualizing criminal procedure and evidence', the last of which is a normative one (ibid. p. 383). 
engage in examination of criminal procedure, whilst those advocating reform to that procedure do not attempt to engage with legal theory. ${ }^{72}$

\section{1 'Fairness' in Criminal Procedure}

There are frequent mentions of 'fairness' in the Scottish reform proposals, but these are often in general terms, rather than being specific to the accused's right to a fair procedure. Thus the Murrayfield lecture refers to a vision of a 'much fairer system of justice for all'. ${ }^{73}$ The 2015 Review talks of the need for a process 'seen to be fair to all the parties involved' $;{ }^{74}$ and 'fairness to the accused and all others concerned. ${ }^{75}$ Next Steps makes only three references to fairness: more effective management of court business could nonetheless meet 'the highest standards of fairness, ${ }^{76}$ there is a need for 'fairness for all those involved in the criminal trial process', ${ }^{\prime 7}$ and trials should proceed 'smoothly and fairly ${ }^{78}$ Explicit reference is sometimes made in the 2015 Review to the accused's right to a fair trial ${ }^{79}$ and to the need to 'secure continuing compliance with the European Convention', ${ }^{80}$ but the proposals also speak of 'the broader principles of fairness to which the justice system aspires, ${ }^{81}$ suggesting that the accused's rights must be considered in the context of fairness to other parties, such as witnesses and victims. Thus even when the need for fairness to the accused is expressed, it is often included as something to be balanced against other considerations. There is no explicit recognition that the rights of the accused to a fair trial are paramount; they must generally trump those of other parties when their rights conflict.

A striking exception is the 3 volume series: The Trial on Trial, edited by Duff, Farmer, Marshall and Tadros: 1: Truth and Due Process (Hart 2004); 2: Judgment and Calling to Account (Hart 2006) and 3: Towards a Normative Theory of the Criminal Trial (Hart 2007).

73 Murrayfield lecture, at 27 (emphasis added).

$74 \quad 2015$ Review, para 1.7.

752015 Review, para 2.73. See also the hope expressed in para 5.9 that the Review will lead to a system of justice that deals with cases speedily, effectively and fairly'.

$76 \quad$ Next Steps, para 28.

$77 \quad$ Ibid. para 39.

78 Ibid. para 29.

792015 Review, para 1.8. But note the context, as previously described above: the ECHR's fair trial requirements are said to be 'expressed at a high level of abstraction'. See also paras 3.33 (discussed further below), 3.49, 3.51, 5.3, and Next Steps, pp. 36, 38, 48 and 65. The more frequent references to the accused's right to a fair trial in the latter document is in part due to the fact that this summarised the views of practitioners who attended the various workshops - and they were keen to emphasise the importance of the accused's fair trial rights.

80 2015 Review, para 3.33.

$81 \quad$ Ibid. 
The accused's rights are added almost as an afterthought in the discussion of vulnerable witnesses: since the experience of testifying in court is 'potentially harmful to young and vulnerable witnesses' it is concluded that 'every step should be taken - consistent with fairness to the accused - to avoid that harm occurring. ${ }^{82}$ In similar fashion, the Review concludes that judicial control will be required to discourage defence lawyers from requiring all prosecution witnesses to testify at trial. Such control is said to be 'quite consistent with the concept of a fair trial. ${ }^{83}$ Where the European Court of Human Rights has not criticised a particular aspect of a legal system's criminal procedure, then this seems to be taken to mean that the procedure in question is compatible with Article 6. In the discussion of cross-examination, the Review explains that 'the rights to a fair trial in Article $6 \ldots$ apply to the entire criminal investigation and prosecution process, and not just to the final trial diet itself ${ }^{84}$ - a statement which appears to be favourable to suspects and accused persons. However, it seems that this is a double-edge sword for the accused. The Review continues:

This means that, on the one hand, procedures have to be consistent with Article 6 rights from the moment that a suspect is identified and apprehended; but on the other, the introduction of the safeguards required, such as those needed to preserve the Convention right of examination, need not be confined to the final trial diet. ${ }^{85}$

The Review then reasons: 'It follows from this that the setting for the cross-examination need not be in the courtroom, ${ }^{86}$ thus bolstering its conclusion that pre-recorded testimony need not breach the accused's rights. In Next Steps, the accused's right to examine prosecution witnesses is described as 'essential for a fair trial'. However, this right was then tied to the need for full and early disclosure of the prosecution's case which would allow the defence to specify which aspects of that case the accused is disputing, and to agree all other evidence, pre-trial. Again, the conclusion is one which whittles down the accused's rights: traditionally, the Scottish system required all witnesses essential to the prosecution's case to testify; henceforth, the defence will be able to challenge 'only those witnesses whose testimony sheds light on the matters in dispute. ${ }^{87}$

As noted above, reports that the statutory time limit is regularly being breached in High Court trials led the Lord Justice General to question whether the current time lim-

\footnotetext{
$82 \quad$ Ibid. para 2.67.

$83 \quad$ Ibid. para 4.22 .

84 Ibid. para 3.41. This is certainly the case: 'even if the primary purpose of Article $6 \ldots$ is to ensure a fair trial by a "tribunal" competent to determine "any criminal charge", it does not follow that the Article has no application to pre-trial proceedings' (Salduz v. Turkey (2009) 49 EHRR 19, para 50.

$85 \quad 2015$ Review, para 3.41.

$86 \quad 2015$ Review, para 3.42.

$87 \quad$ Next Steps, para 30.
} 
it was 'in accord with modern principles of fairness or justice'. One might ask: fairness or justice for whom? Arguably not for the presumptively innocent accused who faces a lengthier period of incarceration on remand. Even many defence lawyers seem to have accepted the inevitability of an extension to the statutory period, with one senior advocate suggesting that 'we should cease the pretence of the rule and replace it with one which is realistic and which is only extended when real cause is actually shown' ${ }^{88}$ Thus, changes are again being proposed to an important aspect of Scottish criminal procedure - and an important safeguard for the accused - without a detailed analysis of its value in the process.

\subsection{Efficiency and the Search for 'the Truth'}

It is noteworthy that the second of the 2015 Review's principles stresses the need for criminal cases to be dealt with 'efficiently'. This is a recurring theme in these reform proposals: there are six references to 'efficiency' and a dozen mentions of 'efficient' or 'efficiently' in the 2015 Review. In the Next Steps document, 'efficiency' or 'efficiencies' appears 13 times. ${ }^{89}$ 'Efficiency' generally refers to the ability of a process or system to achieve a particular objective without wasting resources, including money and time. What, then, is the objective of the criminal process to which efficiencies should be directed? It is clear that for the Review the principal objective is accuracy in fact-finding; it criticises current Scottish criminal trials on the basis that they 'do not operate in a manner best suited to the ascertainment of fact'.$^{0}$ The reform proposals therefore evaluate the criminal process suggestion 140 day rule may not be fit for purpose, 12 January 2016, available at: http://www. scottishlegal.com/2016/01/12/lawyers-respond-to-lord-presidents-suggestion-140-day-rulemay-not-be-fit-for-purpose/.

${ }^{89}$ There is also one reference to 'efficiently', and four to 'efficient'. The terms of reference of the earlier Carloway Review (op. cit.) also included the requirement to maintain 'an efficient and effective system for the investigation and prosecution of crime' (at para 1.0.7). That Review accordingly made 16 additional references to the need for aspects of the criminal justice system to be 'efficient'. Compare the Runciman Commission whose remit referred to the need to have regard to 'the efficient use of resources' in its examination of 'the effectiveness of the criminal justice system' (Runciman Report, p. iii). The most recent review of English criminal procedure was published in January 2015. For a useful summary see Edwards, The other Leveson Report - the Review of Efficiency in Criminal Proceedings, Criminal Law Review (2014) pp. 399-406. It too has been criticised for giving undue priority to dealing with cases 'efficiently, leading to 'wholesale desertion of the [justice] system's proclaimed founding values': Marsh, Leveson's narrow pursuit of justice: efficiency and outcomes in the criminal process, 45 Common Law World Review (2016) pp. 51-67, at 60. As Marsh explains, however, efficiency for Leveson was about cost-cutting, rather than accuracy of the verdict.

$90 \quad$ Murrayfield lecture, at 26-27. 
through the lens of its fact-finding and truth-finding function. This instrumental approach is apparent from the Review's first paragraph:

\begin{abstract}
Although there are some who might argue otherwise, most (and especially those not engaged in the niceties of legal philosophy) would agree that the trial process is about the ascertainment of the truth. The Review's purpose is to explore and identify the best possible methods for ascertaining the truth .... ${ }^{91}$
\end{abstract}

It is of note that this does not say that 'one important part' of the trial process is to ascertain the truth, or even that truth finding is 'the primary objective' of the process. Rather, it asserts that ascertainment of the truth is what the trial process 'is about. ${ }^{92}$ There are no riders, limitations or caveats. The Review's proposals for reform are replete with references to the importance of ascertaining 'the truth. ${ }^{93}$ Thus, inefficiency threatens 'the search for the truth'; ${ }^{94}$ the core aim of the trial is 'discovering the truth'; $;{ }^{95}$ there is a need to preserve the integrity of the trial's 'truth-finding function $;{ }^{96}$ written statements may not be conducive to 'the ascertainment of truth'; ${ }^{97}$ aggressive and confrontational cross-examination may be equally inimical to 'the discovery of the truth'; $;^{98}$ cases which take too long to process have a detrimental effect on the ability of the system 'to do what it is meant to do - ascertain the truth'; 99 by contrast, pre-recorded statements ' will make a positive contribution to the ascertainment of the truth. ${ }^{100}$ In short, as the Review itself puts it, its 'primary concern' is 'to explore how the task of ascertaining the truth in a criminal trial can be supported. ${ }^{101}$ It might be felt that this is a sensible stance for reformers to take - surely the criminal process is about efficient truth-finding - acquitting the innocent and convicting the guilty? The danger here is that elevating the ascertainment of the truth as not merely an important goal of the process, but the only goal, makes it easy to devalue, and

2015 Review, para 1.1, (footnote omitted).

Compare the critique of the Runciman Commission by Nobles and Schiff 2000, at 43: 'The Commissioners' most important concern is the pursuit of truth in terms of the justice of "correct" decisions. Fairness is welcomed to the extent that it contributes to the pursuit of truth, but must occasionally be balanced where the two conflict?

See also Next Steps, paras 38 and 77.

2015 Review, para 1.3.

Ibid. para 1.4 .

Ibid. para 2.73.

Ibid. para 3.20

Ibid. para 3.43

Ibid. para 5.2.

Ibid. para 5.3.

Ibid. para 3.62 . 
perhaps even to abolish, those aspects of the process which do not serve this instrumental function.

\subsection{Moving towards an Inquisitorial System}

If some of the recent reform proposals were to be implemented, the Scottish criminal process would move away from its adversarial roots. If truth-finding is indeed the purpose of the process, as the Review supposes, then the means by which this end is achieved matter little; Scotland should not be averse to borrowing from other systems' criminal procedures, including inquisitorial ones, particularly if we believe that the latter are more committed to searching for - and may well be better at ascertaining - the truth. ${ }^{102}$ The use of pre-trial witness statements in lieu of live testimony, as advocated by the Murrayfield lecture and 2015 Review, is already permitted in the Netherlands and in Germany. ${ }^{103}$ Adoption of a similar approach in Scotland would represent a move towards a more inquisitorial criminal process. As we have seen, Lord Carloway also favoured a more episodic approach to the trial. He initially rejected any suggestion that this would represent a shift away from the traditional adversarial approach on the basis that it would continue to be the parties (the prosecution and the defence) who would be responsible for finding the evidence and putting it before the court. ${ }^{104}$ Party control over the process, rather than control by the court or judge, is certainly a central feature of adversarial systems - but so is the view that the trial marks the culmination of the process at which all the testimony and other evidence must be heard. Indeed, it has been suggested that one hallmark of the adversarial process is that it

draws a clear barrier between the investigatory stage and the following trial phase, so that at the trial the information collected in the preliminary stage is not the basis for the decision. Consequently, it is ensured that evidence will be produced and discussed in Court, in observance of the principles of orality and immediacy. ${ }^{105}$ Code of 1988), 4 Washington University Global Studies Law Review (2005) pp. 567-582, at 56970. See also the reference to 'the oral trial' as 'the centre piece of the adversary system' in Devlin, The Judge (Oxford University Press 1979) at p. 55. 
This requirement for all evidence to be presented to the court for the first time, and on the one occasion - the 'temporal concentration of proceedings, ${ }^{106}$ to use Damaška's phrase - contrasts with the more sequential approach taken in non-adversarial jurisdictions. ${ }^{107}$ Damaška contended that the 'day-in-court'108 trial was one of three 'supporting pillars' of adversarialism. ${ }^{109}$ He went so far as to say that removal of any one of the pillars would mean that 'distinctive common law doctrines and practices [would] require a new interpretive frame in order to maintain their vitality - indeed, to survive. ${ }^{110}$ If Scotland were to adopt a more episodic approach to the hearing of evidence, this too would represent a shift towards the inquisitorial model. ${ }^{111}$ Perhaps this is a change the Scottish system should make - but it should do so in the awareness of what it means for its system of criminal procedure as a whole.

By the time of the 2015 Review Lord Carloway seems to have reconsidered the view that this more episodic approach would not be a break with the adversarial tradition:

The trial hearing itself would become the culmination of an evidence gathering and testing exercise, rather than the entire exercise. This would move the concept of the trial further away from the traditional adversarial approach, with its focus on the trial diet itself, and closer to methods deployed successfully to record what is regarded as evidence in inquisitorial systems. ${ }^{12}$

106 'Concentration' refers to the trial being a single event, rather than comprising several stages. In Sweden, the Code of Judicial Procedure establishes the principle of concentration, which is regarded as ensuring proper examination of the evidence: En modernare rättegång (A More Modern Trial) (2001: 103, Swedish Government Official Reports) at 26. I am grateful to Dr Gustaf Almkvist for a copy of this Report.

107 When Mexico moved from an inquisitorial to an adversarial model of criminal procedure in 2008, it amended its Constitution to make explicit that its criminal procedure 'shall be accusatory and oral' and that the proceedings 'shall be governed by the principles of open proceedings, confrontation, concentration, continuity, and immediacy'. See Méndez, Shifting from the inquisitorial to the adversarial model in criminal cases: is a hearsay rule indispensable? 5 Florida International University Law Review (2009-2010) pp. 13-40, at 13.

108 Damaška, Evidence Law Adrift (Yale University Press 1979) at p. 130.

109 Ibid. at 4. The other two pillars are the 'peculiar organization of the Trial Court' (by which Damaška meant the bifurcation between judge and jury), and the 'prominent role of the parties and their counsel in legal proceedings' (ibid).

$110 \quad$ Ibid.

111 For the argument that Scottish criminal evidence law has already moved some way towards a non-adversarial system see Duff, Intermediate diets and the agreement of evidence: a move towards an inquisitorial culture? Juridical Review (1998) pp. 349-367, and Duff, Disclosure in Scottish criminal procedure: another step in an inquisitorial direction, International Journal of Evidence and Proof (2007) pp. 153-180.

$112 \quad 2015$ Review, para 4.1. 
Since adversarial lawyers traditionally evince hostility towards non-adversarial procedures, one might expect the Review to describe the merits of inquisitorialism, or offer a comparison of the strengths and weaknesses of the two different approaches, but this is not attempted. Again we see a parallel with the Runciman Commission, which stated:

we have not arrived at our proposals through a theoretical assessment of the relative merits of the two legal traditions. On the contrary, we have been guided throughout by practical considerations in proposing changes which will, in our view, make our existing system more capable of serving the interests of both justice and efficiency. ${ }^{113}$

A footnote in the Scottish 2015 Review informs the reader that

\begin{abstract}
In Ireland, the 'unity of the trial' is an important legal concept with quasi-constitutional force, which has inhibited the introduction of pre-trial case management procedures generally ... - see People (AG) v McGlynn ... where the Irish Supreme Court held that an uninterrupted 'unitary' jury trial is essential to the requirements of due process. ${ }^{114}$
\end{abstract}

In light of the importance that Ireland - also an adversarial jurisdiction - places on the unity of the trial, it is surprising that the values this concept embodies are not then assessed.

It was noted above that the law relating to hearsay evidence will require amendment if these reform proposals are implemented. Lord Carloway's recommendations here stem from a desire for Scottish law to abolish all 'technical rules concerning the admissibility of testimony' in favour of 'a system which allows a free approach upon the part of the fact finder to determine what is proved from all available information. ${ }^{115}$ The drive to rid the law of evidence of many of its exclusionary rules is reminiscent of the Continental approach to 'free proof' - another step in the inquisitorial direction. 'Free proof' has two meanings: freedom to admit any relevant evidence (la liberté des preuves), or freedom to assess that evidence as the court sees fit (la liberté d'apprèciation). ${ }^{116}$ The first sense is similar to the reforms advocated for English law nearly 200 years ago by the utilitarian philosopher Jeremy Bentham. According to Bentham, 'in principle there is but one mode of searching out the truth ... see everything that is to be seen; hear everybody who is likely to

113 Runciman Report, para. 12.

1142015 Review, footnote 110.

115 Murrayfield lecture, p. 20. See also the Carloway Review, para 7.2.53: 'it is a hindrance, rather than an advantage, to have to apply rules which prohibit a judge or jury from reaching a just conclusion based upon a liberal consideration of all relevant testimony'.

116 See Margot, The role of the forensic scientist in an inquisitorial system of justice, 38 Science and Justice (1998) pp. 71-73, at 71. In Sweden the principle of free proof includes free presentation and evaluation of evidence: En modernare rättegång, at p. 26. 
know anything about the matter....'117 Lord Carloway's reference to the trial judge having access to 'all available information' suggests that he had in mind the former definition, while his call for the judge to be permitted 'a free approach ... to determine what is proved' suggests the latter. It should be noted, however, that the belief that judges in inquisitorial systems are free to assess the evidence as they wish is somewhat fallacious: trial judges in such systems are required to provide reasoned verdicts. These are liable to be carefully scrutinised by appeal courts, thus they must demonstrate that they assessed the evidence in a rigorously rational fashion. ${ }^{118}$ By contrast, there is no requirement for a Scottish jury (or judge) to demonstrate that it has engaged in a similar reasoning process. In short, there may be dangers in adopting a 'free proof' approach without a fuller appreciation of this context.

It is perhaps unfair to expect Lord Carloway, - or indeed any judge who is embarking on reform - to provide a fully developed, normative account of the criminal process; many academic lawyers and legal philosophers have wrestled with this thorny problem, but few have succeeded. ${ }^{119}$ Nevertheless, without a better developed philosophy of Scottish criminal procedure we are in danger of making changes in a piecemeal fashion, with insufficient regard to how the process ought to operate, as a whole.

\section{Non-instrumental Concerns: Beyond Truth Discovery}

Lord Carloway is of course correct in asserting that one purpose of the criminal trial is to determine the truth of the charge which has been made against the accused. None would doubt that a central aim of criminal procedure is to convict the guilty and acquit the innocent. An instrumental approach to criminal procedure assesses the process as a whole, as well as its various components, according to how well or badly it secures this 'right result.' This was advocated in the $19^{\text {th }}$ century by Bentham, who believed that the object of criminal procedure was to produce an accurate outcome ${ }^{120}$ or 'rectitude of the decision', to use his terminology. Many of the rights guaranteed by the ECHR are designed to contribute to accurate fact-finding. Thus, a tribunal is more likely to arrive at an accurate verdict: if it is independent of the parties and behaves impartially; if the defence is given adequate time and resources to challenge and/or rebut the prosecution's case; and if the

117 Bentham, Rationale of Judicial Evidence (1827), available at: http://oll.libertyfund.org/titles/ bentham-the-works-of-jeremy-bentham-vol-7-rationale-of-judicial-evidence-part-2 at 599.

118 Stein, A political analysis of procedural law, 51 Modern Law Review (1988) pp. 659-675, at 664. See also van Koppen 2007 p. 55: ' ...in a Dutch court, judges have to give a written decision and they have to argue what evidence they used for that decision'.

119 But see note 72, above, and the work of Antony Duff more generally, for a notable exception.

120 Bentham, Rationale of Judicial Evidence (1840) Book VI, at p. 129. 
trial is conducted in an expeditious manner with no undue delay so that the memories of witnesses do not become impaired by the passage of time.

Jackson and Summers have summarised the limitations in truth-finding inherent in the adversarial process:

\begin{abstract}
On one view, 'adversarial' systems are deeply flawed because the parties responsible for gathering and presenting the evidence are deeply partisan, with the result that the informational sources used are highly selective and become distorted. This partisan manner of collecting evidence is carried into the trial where the process of examination and cross-examination imposed upon witnesses results in a highly skewed picture of reality being conveyed to the triers of fact. The winner ... is not the party with the most truth on his side, but the side that has the most wealth to marshal the best legal resources. The triers of fact, meanwhile, are forced to maintain a position of neutral passivity in such a contest and are unable to harness the contest towards the kind of active enquiry that would be required to make the enterprise a serious truth-finding endeavour. ${ }^{121}$
\end{abstract}

Adversarial systems could be better designed in order to improve their truth-finding function - but this is not their sole purpose. Rather, they incorporate important limitations on the search for the truth in order to uphold other values. These include the need to ensure: (a) that doubts about guilt or innocence should be resolved in favour of the accused, and (b) that the criminal process maintains, and demonstrates that it maintains, its moral legitimacy. The maintenance of moral legitimacy requires that the state does not over-reach itself by trampling on citizens' rights in its enforcement of the criminal law.

\title{
5.1 Erring on the side of Innocence
}

As noted previously, both the Runciman Commission and the 2011 Review treat 'miscarriage of justice' to mean 'getting the verdict wrong', whether by convicting the innocent or by acquitting the guilty. ${ }^{122}$ This interpretation is one that has found favour with some scholars. Walker, for example, contends that there is a miscarriage of justice 'when a jury perversely refuses to convict an individual, ${ }^{123}$ while Hughes goes so far as to say that 'injustice is done by failing to punish the guilty just as much as by punishing the innocent. ${ }^{124}$

121 Jackson and Summers, The Internationalisation of Criminal Evidence: Beyond the Common Law and Civil Law Traditions (Cambridge University Press 2012) at p. 10.

122 See text at note 17 , above.

123 Walker, Miscarriage of justice in principle and practice in Miscarriages of Justice: A Review of Justice in Error, eds. Walker and Starmer (Blackstone Press 1999) pp. 31-64, at 36.

124 Hughes, English criminal justice: is it better than ours? Arizona Law Review (1984) pp. 507614 , at 514. 
We can distinguish between 'factual guilt' (the accused did, as a matter of fact, commit the crime), and 'legal guilt' (the prosecution has established beyond a reasonable doubt that the accused committed the crime). ${ }^{125}$ It is certainly true that public concern is engendered when those who are widely believed to be 'factually guilty' are acquitted, ${ }^{126}$ and the principle of double jeopardy (non bis in idem) has been limited in some jurisdictions due to concerns that some 'patently guilty' people have been acquitted. ${ }^{127}$ There remains, however, a widely-held perception that a wrongful conviction is a far more serious wrong than a mistaken acquittal. ${ }^{128}$ The Runciman Commission's failure to distinguish between the two met with strong criticism. ${ }^{129}$ For instance, Wells referred to the Commission's

crude deployment of a binary opposition between .... the need to avoid the acquittal of the guilty and the conviction of the innocent.... these are not harms of equal or even equivalent gravity ... the juxtaposition of wrongful convictions with 'wrongful' acquittals obscures the very real difference between them. ${ }^{130}$

125 See Packer, Two models of the criminal process, 113 University of Pennsylvania Law Review (1964) pp. 1-68; Packer, The Limits of the Criminal Sanction (Stanford University Press 1968) p. 161. For the implications of this for the presumption of innocence, see Ferguson, The presumption of innocence and its role in the criminal process, 27 Criminal Law Forum (2016) pp. 131-158, at 137-140.

126 It has been suggested that OJ Simpson, in the USA, and those who are alleged to have murdered Stephen Lawrence, in England, are examples of this: see Tonry, 'Wrongful' acquittals and 'unduly lenient' sentences - misconceived problems that provoke unjust solutions, in Principles and Values in Criminal Law and Criminal Justice: Essays in Honour of Andrew Ashworth, eds. Zedner and Roberts (Oxford University Press 2012) pp. 307-324, at 308.

127 Scotland has now several exceptions to the double jeopardy principle: see the Double Jeopardy (Scotland) Act 2011. A person can now be re-tried where the acquittal occurred due to an attempt to pervert the course of justice (for example, by interfering with witnesses or other evidence); where the accused admitted guilt after being acquitted; and where new evidence of guilt has subsequently come to light. For England see the Criminal Procedure and Investigations Act 1996, pp. 54-57, and the Criminal Justice Act 2003, p. 78.

128 For empirical research on those who have been exonerated following wrongful conviction, see DeShay, 'A lot of people go insane behind that': coping with the trauma of being wrongfully convicted, 29 Criminal Justice Studies (2016) pp. 199-213.

129 Lacey 1994 p. 32. See also: Bridges and McConville, in Criminal Justice in Crisis, eds. McConville and Bridges (Edward Elgar 1994) at p. 6.

130 Wells, The Royal Commission on Criminal Justice: a room without a view, pp. 51-58, at 56. See also Hodgson, The future of adversarial criminal justice in $21^{\text {st }}$ century Britain, North Carolina Journal of International Law \& Commercial Regulation (2010) pp. 319-362, at 326: 'the Commission was asked to consider the conviction of the guilty as well as, and indeed before, the acquittal of the innocent ... [its] error of judgment lies in treating these two objectives as being of equal importance and as being inextricably bound together'. 
Fact-finding in criminal trials is not an exact science and there will always be a danger of errors, leading to incorrect verdicts. While a wrongful conviction and a mistaken acquittal are both erroneous verdicts, the criminal process does not, and should not, treat them as equally problematic. How we allocate the risk of error is a matter of political morality, dependent on the values a society wishes to promote; one such value is that we should make great effort to avoid convicting the innocent. ${ }^{131}$ Criminal justice systems have devised safeguards and conferred rights on those accused of having committed crimes in order to protect against this risk. ${ }^{132}$ We make it difficult for the prosecution to secure a conviction by having a presumption of innocence which places the burden of proving guilt on the prosecution, rather than requiring accused persons to prove that they are innocent. We mandate an acquittal unless guilt is proven to a very high standard: 'beyond a reasonable doubt'. As previously noted, Scotland currently offers further protection in demanding that guilt be established from more than one source of evidence: the requirement for corroboration. Such safeguards stem from an abhorrence of wrongful convictions.

A similar concern is reflected in Blackstone's famous maxim that 'it is better that ten guilty persons escape, than that one innocent party suffer. ${ }^{133}$ Different ratios have been suggested such as 50 guilty persons to one innocent, or even 100 to one. There is, of course, no 'correct' ratio; the proportion we decide upon does not reflect the extent to which we are prepared to tolerate mistaken convictions. ${ }^{134}$ Rather, the maxim reflects the belief that wrongful convictions are a particularly grave injustice. ${ }^{135}$ Quite often rules of evidence provide for exclusion of relevant material despite its reliability and persuasive nature because there may be other, countervailing considerations which outweigh the benefits to be achieved from its admission. The prejudicial effect of allowing the evidence to be heard may be greater than its probative value. Previous convictions are one example

131 See Stein, The refoundation of evidence law, 9 Canadian Journal of Law and Jurisprudence (1996) pp. 279-342, at 285. See also Stein, Against 'free proof', 31 Israel Law Review (1997) pp. 573-589. Laudan notes that: 'Since virtually everyone agrees that convicting an innocent person is a more costly mistake than acquitting a guilty one, a whole body of doctrine and practices has grown up in the common law about how to conduct trials so as to make it more likely that, when an error does occur, it will be a false acquittal rather than a false conviction'. Laudan, Truth, Error and Criminal Law: An Essay in Legal Epistemology (Cambridge University Press 2006) pp. 1-2.

132 See Stein, Against 'free proof', ibid., at 579. See also Jackson and Summers 2012 p. 21: 'By the mid nineteenth century, there was a consensus that the legitimacy of the process meant that every effort had to be made to avoid wrongful convictions'.

133 Blackstone, Commentaries on the Law of England (1783), Book IV, p. 358. For the argument that wrongful convictions may not be worse than wrongful acquittals see: Epps, The consequences of error in criminal justice, 128 Harvard Law Review (2015) pp. 1065-1151.

134 Halvorsen, Is it better that ten guilty persons go free than that one innocent person be convicted? 23 Criminal Justice Ethics (2004) pp. 3-13.

135 For an attempt to explain this belief see Ferguson 2016 pp. 147-149. 
of this. ${ }^{136}$ Knowing that an accused has a previous conviction for theft, for example, tells the fact-finder that the accused is not the most honest of persons, but does little to assist in determining whether he is guilty of committing the crime being tried before the court if that crime is robbery, or fraud. There is, however, a real danger that the fact-finder will give a minor theft conviction undue weight and decide that a person who has stolen once may well have graduated to stealing with violence, or has committed other acts of dishonesty. ${ }^{137}$ This is an especial danger if the fact-finder is a jury comprised of lay-people. ${ }^{138}$ Some fact-finding accuracy may therefore have to be sacrificed to ensure that the risk of error falls heavily on the side of wrongful acquittals. ${ }^{139}$ By focusing on 'efficiency' and 'truth-finding', and viewing acquitting the innocent and convicting the guilty as equally important, reformers are in danger of losing sight of this 'prime directive' of criminal procedure: 'to protect the innocent at all reasonable costs. ${ }^{140}$

\subsection{The Maintenance of Moral Legitimacy}

As previously noted, the criminal process embodies certain non-instrumental values which are neither related to truth-finding accuracy nor exclusively concerned to minimise the likelihood of convicting the innocent. ${ }^{141}$ Those who wish a broad interpretation

136 The Criminal Procedure (Scotland) Act 1995, s. 101(1) states: 'Previous convictions against the accused shall not [subject to some exceptions] be laid before the jury, nor shall reference be made to them in presence of the jury before the verdict is returned'. Section 166(3) is a similar provision for summary procedure (i.e. where there is no jury).

137 For an excellent discussion of the relevance of evidence of previous convictions see Redmayne, Character in the Criminal Trial (Oxford University Press 2015).

138 It has, however, been suggested that 'there is little support in psychology for the proposition that only novice fact finders succumb to the temptation of drawing overly negative conclusion from an individual's unsavory life history, while professional judges are immune to the seductive song of propensity inference': Damaška, The jury and the law of evidence: real and imagined interconnections, 5 Law, Probability and Risk (2006) pp. 255-326, at 257.

139 See also Goodpaster, On the theory of the American adversary criminal trial, 78 Journal of Criminal Law and Criminology (1987) pp. 118-154, at 135: 'Because of the serious consequences of criminal convictions, it is better to risk erroneous acquittals than erroneous convictions. Criminal trials, therefore, should be structurally skewed to favour acquittals'.

140 See Thomas 'The criminal procedure road not taken: due process and the protection of innocence', 3 Ohio State Journal of Criminal Law (2005) pp. 169-200, at 170.

${ }_{141}$ '[P] ursuit of the truth is only one component of adjudicative activity ... truth enhancing values must be balanced against other countervailing needs of the legal process, such as social peace, human rights, stability of decisions, or costs'. Damaška, Epistemology and legal regulation of proof, 2 Law, Probability and Risk 2 (2003) pp. 117-130, at 117. See also Damaška, Truth in adjudication, 49 Hastings Law Journal (1998) pp. 289-308, at 289: the 'accuracy [of the verdict] is not the sole measure of the value of adjudicative fact-finding: social needs and values are recognized that constrain the pursuit of the truth. 
to be given to 'miscarriages of justice' may wish to reflect on the fact that even a factually guilty person whose guilt has not been established beyond a reasonable doubt to the satisfaction of an independent and impartial tribunal, following established rules of evidence, has been 'wrongly convicted.' ${ }^{142}$ Moral legitimacy has been defined as

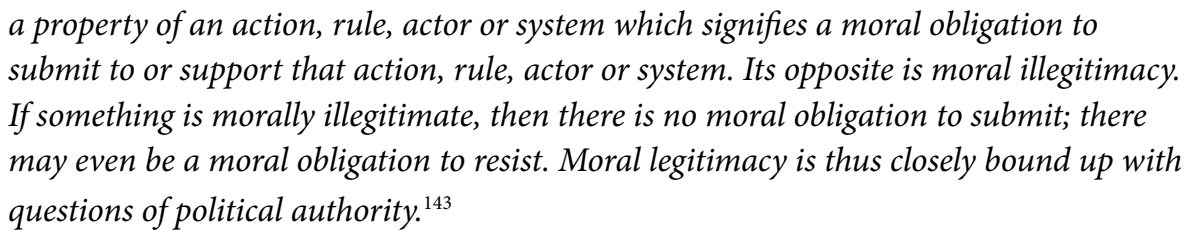

If a court resolved to convict on the basis of the toss of a coin, ${ }^{144}$ the accused could justifiably complain about a lack of fair procedure - and this applies whether or not the accused is factually innocent. A verdict based on a coin toss would be devoid of moral legitimacy. Conviction of an accused involves condemnation and punishment. Punishment is, by definition, an evil; it requires to be justified and it is only justified where an accused has breached society's criminal law norms, and where the nature and extent of the punishment is decided upon and inflicted by one who has both the legal and moral right to do so. Thus we condemn vigilante 'justice', even if we are in no doubt that the right person was punished, because the punishment has come from an illegitimate source. Depriving individuals of their freedom, taking their money without consent, or forcing them to perform unpaid labour are all unlawful acts unless they stem from a criminal conviction, and it is the state which is the actor. The state must establish the breach of norms to a high degree of certainty, such that we are convinced of the accused's guilt beyond a reasonable doubt. It is this guilty verdict which gives the state the moral authority to condemn and punish the convicted person.

The state must demonstrate the legitimacy of the process leading to each conviction. Important process values flow from this requirement:

- The state (and its officials: the police, prosecution and judiciary) must behave with the utmost propriety since those who sit in judgement of others must themselves be beyond reproach. In particular, the state must not condemn those who violate society's norms while simultaneously engaging in, or condoning, behaviour which itself violates those norms.

142 See Hughes, Innocence unmodified, 89 North Carolina Law Review (2011) pp. 1083-1124, at 1089 , arguing that 'the innocent' includes those who are factually guilty, but who have been convicted in derogation of their procedural rights.

143 Thomas, The concept of legitimacy and international law, LSE Law, Society and Economy Working Papers 12/2013, pp. 1-32, at 11.

144 This way of deciding the case is alleged to have occurred in Vaise v Delaval (1785) 99 ER 944. 
- The state must not treat citizens unfairly and must not act in disregard of their process rights. The state must refrain from treating those who are suspected of having committed a crime as if they had already been convicted, when this has yet to be determined. ${ }^{145}$

Where the police have overstepped their authority and trampled on rights, the trust between state and citizen is breached, and the state lacks the moral authority to condemn and punish. Thus, confession evidence obtained by state torture or threats of torture should be inadmissible, even if there is independent corroboration which supports the truth of the confession. ${ }^{146}$ Courts should refuse to countenance such evidence, not merely because it may be unreliable (threatened with physical pain, many of us will 'admit' to whatever is required from us), but because even the threat of torture taints any evidence obtained as a result; the state loses the moral high ground, and the system lacks integrity. Evidence obtained by means of entrapment of the accused by officials employed by the state has a similar effect. ${ }^{147}$ In the same way, if there has been disregard of process rights, such as the right to a fair and timely trial, the right to challenge the prosecution evidence, the right to confront one's accusers, etc. 'the truth' may be revealed and the facts accurately found, but the trial itself is morally redundant.

As we have seen, the Scottish reform proposals raise doubts about the value of defence cross-examination. This is a controversial stance; the majority of common law defence lawyers may well agree with Wigmore's oft-quoted words that cross examination is 'the greatest legal engine ever invented for discovery of truth. ${ }^{148}$ This is a topic on which much might be said, ${ }^{149}$ and a detailed exposition of the values underlying the right to

146 See, for example, A and others v. Secretary of State for the Home Department (No. 2) [2005] UKHL 71, in which the House of Lords held that information obtained from torture should not have been admitted as evidence. For a summary of the case see Thienel, Foreign acts of torture and the admissibility of evidence, 4 Journal of International Criminal Justice (2006), pp. 401-409.

147 According to the ECtHR, ‘... the right to a fair administration of justice ... holds such a prominent place that it cannot be sacrificed for the sake of expedience ... the public interest cannot justify the use of evidence obtained as a result of police incitement': Texeira de Castro v. Portugal (1999) 28 EHRR 101, at para 36. See also Ramanauskas v. Lithuania [2008] Crim L R 639/ (2010) EHRR 11 .

148 Wigmore, Evidence in Trials at Common Law, (Chabourn (ed.) 1974) at p. 32. As Wigmore also noted, however: 'A lawyer can do anything with cross-examination ... [and] may ... make the truth appear like falsehood' (ibid).

149 See, for example: Henderson, Bigger fish to fry: should the reform of cross-examination be expanded beyond vulnerable witnesses? International Journal of Evidence \& Proof (2015) pp. 8399; Henderson, 'Did you see the broken headlight?' Questioning the cross-examination of robust adult witnesses, Archbold Review (2014) pp. 4-6; Epstein, The great engine that couldn't: science, mistaken identifications, and the limits of cross-examination, 36 Stetson Law Review (2007) pp. 727-787. For the suggestion that a more subtle form of cross-examination may be more effective than the stereotypical aggressive form, see Rutberg, Conversational cross-examination, 9 American Journal of Trial Advocacy (2005-6) pp. 353-394. 
confront or examine witnesses would have helped to further the debate. Instead, the Review's main argument is that since defence cross-examination of witnesses at trial does not feature in many Continental European jurisdictions, there is no right to this form of cross-examination required by the ECHR. ${ }^{150}$ The focus here is again on instrumental values: cross-examination may be modified or perhaps even dispensed with if the truth can be sought by other means. Such an approach ignores its intrinsic process value: the accused should be entitled to cross-examine witnesses as part of the participation rights which a person who is being prosecuted ought to have. ${ }^{151} \mathrm{~A}$ similar point can be made about proposals to reform the law relating to hearsay evidence. Hearsay is not excluded solely because it is felt to lack probative value, but also because those who have been accused of breaking the criminal law ought to be given a fair opportunity to confront their accusers. As Stein puts it:

Factual findings that could be made on the basis of unexamined testimonial evidence could possibly be accurate, but their accuracy is not the issue. The issue is whether [a] community where criminal trials are allowed to be conducted without full participation of the defendants is politically attractive. ${ }^{152}$

Of course, in practice this participation is often by defence lawyers, rather than by the defendants themselves. This can be justified on the basis that lawyers tend to be better educated and more articulate than defendants, and are thus better able to represent their interests.

Summers employs the term 'consensualism' to describe the right not to participate. ${ }^{153}$ In the Scottish criminal process, this manifests itself in the accused's right to remain silent during police questioning, and to refuse to testify. This privilege against self-incrimination and right to silence ${ }^{154}$ may also be viewed as an aspect of the right to personal priin Norway, and by investigating judges in the Netherlands: see 2015 Review, para 3.39.

151 See Dennis, The right to confront witnesses: meanings, myths and human rights, Criminal Law Review (2010) pp. 255-274, at 266. This argument is bolstered by findings from research on procedural justice which suggest that where parties have been given participation rights, they tend to regard the process as fairer, regardless of the outcome: see Jackson and Summers $2012 \mathrm{p}$. 24.

$152 \quad$ Stein 1996 pp. 292-293.

153 Summers, Evaluating and improving legal processes - a plea for 'process values', 60 Cornell Law Review (1974) pp. 1- 52, at 24.

154 The European Court of Human Rights has referred to this as a recognised international standard which lies at the heart of the notion of a fair trial: Saunders v. United Kingdom (1997) 23 EHRR 313 , para 68 . 
vacy. ${ }^{155}$ The search for the truth in criminal cases may necessitate some breach of privacy rights; the police may require to search the accused's property, or even his or her person, but this must be done in accordance with the law, and unwarranted violations of privacy rights may lead to evidence being excluded at trial.

Another process value is the importance of a verdict which has been determined by the application of reason: a logical verdict based on the evidence. ${ }^{156}$ According to Summers, this requires a fact-finder to 'carefully ascertain relevant evidence and carefully canvas relevant argument'; 'carefully weigh that evidence and argument,' 'deliberate calmly and carefully', 'resolve issues impartially and therefore solely on the basis of their merits', and 'be prepared to give reasons for what is decided. ${ }^{157}$ Finally, reference was made previously to the right to trial within a reasonable time; this value reflects the maxim that 'justice delayed is justice denied.'.58 Before deciding to increase pre-trial time limits we should consider the values which lie behind this procedural right. It is of course of instrumental value in that speedy trials help to prevent degrading of evidence, but it also serves to ensure that those who are accused of criminal wrongdoing do not have to suffer the hardships of an impending trial such as loss of liberty and reputation, and anxiety about the future, for longer than is necessary. Proposals to extend pre-trial detention periods need to address such non-instrumental considerations, rather than focussing only on the difficulties faced by the prosecution in amassing evidence in the modern world.

\section{Conclusion}

The latest reform proposals raise important issues about how best to modernise Scottish criminal procedure, and make several insightful recommendations. It is hardly surprising that the focus of reform is on enhancing the trial's truth-finding abilities; as Thornburn notes:

For most criminal law theorists ... the criminal trial serves only an instrumental purpose... [It is] a sort of 'diagnostic tribunal', a place where the court simply examines

155 See Schafer, Privacy: a philosophical overview, ch. 1 in Aspects of Privacy Law, ed. Gibson (Butterworth 1980) pp. 1-20 at 14: the 'ideal of privacy is clearly one of the fundamental values of our culture'. Privacy is safeguarded by the Fourth Amendment to the US Constitution, which protects against unreasonable search and seizures of person or property, by Section 8 of the Canadian Charter of Rights and Freedoms, and by Article 8 of the ECHR.

156 This was also championed by Fuller: 'By and large it seems clear that the fairness and effectiveness of adjudication are promoted by reasoned opinions [being given by the judge]' (Fuller, The forms and limits of adjudication, Harvard Law Review (1978) pp. 352-409, at 388.

$157 \quad$ Summers 1974 p. 26.

$158 \quad$ Ibid. at 27. 
the forensic evidence to determine whether it is sufficient to establish that the accused has indeed committed the offence with the requisite fault and without justification or excuse. ${ }^{159}$

This paper has questioned the orthodox approach. In treating the finding of 'the truth' as their starting premise, the proposals equate mistaken acquittals with wrongful convictions, thereby failing to appreciate that it is of far greater importance that we minimise the latter than the former. The paper has also suggested that rather than assuming that accurate fact-finding is the raison dêtre of the criminal process, asking whether particular features serve to enhance this goal, and reforming or even abolishing those features which fail to do so, we need to foster greater debate about some of the non-instrumental goals which the process serves. We should then consider how aspects of our current procedure enhance or detract from these other goals. Finally, it has been argued that the rationale for many features of Scottish criminal procedure lies in the furtherance of one particularly important goal, namely the maintenance of the state's moral legitimacy to condemn and punish offenders. at 744 . 